\title{
Mineral composition of beetroot treated with potential elicitors and inoculated with Meloidogyne javanica
}

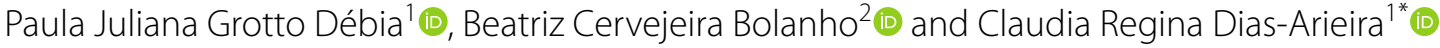

\begin{abstract}
Background: The root-knot nematode Meloidogyne javanica can infect beetroots, causing extensive damage to this food crop. As chemical and genetic control tactics have shown limited efficacy, new strategies are needed to improve the integrated management of this parasite. This study assessed the influence of potential defence elicitors and $M$. javanica infection on the mineral composition of beetroot. Plants were treated with acibenzolar-S-methyl (ASM), citrus biomass, or a mannanoligosaccharide-based product (MOS) and inoculated with 1000 eggs and second-stage juveniles of M. javanica. At 60 days after inoculation, beetroot plants were harvested and evaluated for nematode population density, vegetative growth, and mineral content.

Results: All potential elicitors reduced nematode population density in beetroots $(p \leq 0.10)$ and improved the vegetative parameters of inoculated plants $(p \leq 0.05)$, except shoot fresh weight. Some minerals were found to be negatively affected by treatments, particularly calcium, whose levels were consistently lower in treated plants. On the other hand, M. javanica inoculation increased magnesium, iron, manganese, zinc, and copper contents in beetroots. However, the latter mineral (Cu content) of inoculated plants was positively influenced by MOS and ASM.

Conclusion: Potential elicitor treatments did not improve the mineral composition of beetroot, but were effective in reducing nematode population density. Plants inoculated with $M$. javanica had higher mineral levels. However, gall formation decreases the commercial value of the crop and might render it unsuitable for commercialisation. $M$. javanica-infected beetroots may be used for nutrient extraction or sold to food processing industries.
\end{abstract}

Keywords: Beta vulgaris, Root-knot nematode, Defence mechanism, Macronutrient, Micronutrient

\section{Background}

Beetroot (Beta vulgaris L.) is a highly nutritious vegetable consumed around the world, whether fresh, minimally processed, canned, or as part of baby food and supplements [23]. The taproot is rich in health-promoting bioactive compounds [6] and minerals such as potassium $(\mathrm{K})$, sodium $(\mathrm{Na})$, phosphorus $(\mathrm{P})$, calcium $(\mathrm{Ca})$, and iron $(\mathrm{Fe})$ [32]. Macro- and micronutrients present in beetroots

\footnotetext{
*Correspondence: crdarieira@uem.br

1 Departamento de Agronomia, Programa de Pós-Graduação em Agronomia, Universidade Estadual de Maringá, Avenida Colombo, 5790, Maringá, PR CEP 87020-900, Brazil

Full list of author information is available at the end of the article
}

are responsible for plant growth and development [10] and also play an important role as dietary nutrients, contributing to health promotion and disease prevention in humans [12].

Nutrient absorption and accumulation in plants can be compromised by abiotic and biotic factors, including nematode infection. Root-knot nematodes (Meloidogyne spp.) are among the most destructive plant parasites, and within the genus, Meloidogyne javanica (Treub) Chitwood and M. incognita (Kofoid \& White) Chitwood are especially damaging to beetroot crops. The main symptom of nematode infection is the presence of root galls, derived from complex physiological and biochemical changes caused by parasitism. Such changes lead to cell 
hypertrophy and hyperplasia, compromising water and nutrient absorption by roots and consequently impairing plant growth and yield [15]. However, the extent to which nematode infection affects macro- and micronutrient absorption varies according to nematode sex, inoculum level, and host age [20]. Although infected plants generally show symptoms of nutritional deficiency, an increase in Ca content was observed in potatoes infected with cyst nematodes (Heterodera glycines Ichinohe) [11].

In this context, some environmentally friendly practices that improve the nutritional status of the plant, can favour the vegetative development and, consequently, minimise the damage caused by pathogens, allowing greater absorption of nutrients and gain in productivity $[4,5,16]$. Furthermore, due to the recent restrictions on the use of chemical nematicides and the lack of effective alternatives for nematode control, extensive research has been conducted in an effort to find novel control strategies. Induction of plant resistance to pathogens by application of inductors is gaining attention. This strategy is used to stimulate latent defence responses in plants against nematode penetration and multiplication [5, 8], such as activation of defence enzymes (e.g. catalase, peroxidase, and phenylalanine ammonia-lyase), phenol accumulation, and lignin synthesis. However, few studies have investigated the effects of elicitor treatments on the mineral concentration of food crops infected with nematodes. The current study aimed to assess the mineral composition of beetroot inoculated with $M$. javanica and treated potential elicitors of plant defence.

\section{Methods}

\section{Greenhouse experiment}

The experiment was conducted from January to March 2017 in a greenhouse $\left(23^{\circ} 47^{\prime} 34.5^{\prime \prime} \mathrm{S} 53^{\circ} 15^{\prime} 22.1^{\prime \prime} \mathrm{W}\right.$, $430 \mathrm{~m}$ elevation) at the Laboratory of Nematology of the State University of Maringá, Paraná, Brazil. The experimental arrangement was Completely Randomised Design in factorial scheme $4 \times 2$ (three potential elicitors and water as control; with or without nematode inoculation). Five replications were used for analysing nematode parameters and three for determining mineral composition.

Seeds of hybrid 'Kestrel' beetroot (Sakata Seed Sudamérica Ltd., Brazil) were sown in polypropylene trays containing potting substrate (Bioplant, Brazil). At 15 days after sowing, seedlings were treated with the potential inductors or water (control). Three products were used: Agro-Mos ${ }^{\circledR}$ (MOS), a commercial product containing phosphorylated mannanoligosaccharides from Saccharomyces cerevisiae, $28.04 \mathrm{~g} \mathrm{~L}^{-1}$ sulphur (S), $36.90 \mathrm{~g} \mathrm{~L}^{-1}$ copper $(\mathrm{Cu})$, and $24.60 \mathrm{~g} \mathrm{~L}^{-1}$ zinc (Zn) (Alltech Crop Science, Brazil); Ecolife ${ }^{\circledR}$ (citrus biomass), a commercial product containing $108.3 \mathrm{~g} \mathrm{~L}^{-1}$ organic carbon, $1.71 \mathrm{~g} \mathrm{~L}^{-1}$ boron (B), polyols, and carboxylic acids (Quinabra Brazilian Natural Chemistry Ltd., Brazil); and Bion ${ }^{\circledR} 500$ WG (acibenzolar-S-methyl, ASM, $500 \mathrm{~g} \mathrm{~kg}^{-1}$; Syngenta, Brazil). MOS, citrus biomass, and ASM were applied at the manufacturers' recommended doses $\left(0.5 \mathrm{~g} \mathrm{~L}^{-1}, 2.0 \mathrm{~mL} \mathrm{~L}^{-1}\right.$, and $1.5 \mathrm{~mL} \mathrm{~L}^{-1}$, respectively) by spraying the leaves to the point of runoff. Treatments were reapplied 25 days later, in order to simulate what is done by farmers in the field.

Five days after the first treatment, the seedlings were transplanted, one per pot, into pots containing $2.8 \mathrm{~L}$ of a previously autoclaved $\left(2 \mathrm{~h}, 120^{\circ} \mathrm{C}\right)$ mixture of sandy soil, potting substrate, and sand $(2: 1: 1 \mathrm{v} / \mathrm{v} / \mathrm{v})$. Then, plants were inoculated with $1000 \mathrm{M}$. javanica eggs and secondstage juveniles (J2). The inoculum was obtained from a single-species population of $M$. javanica maintained on tomato. Nematodes were extracted by a standard procedure [1], and the nematode suspension was calibrated to 1000 eggs $+\mathrm{J} 2 \mathrm{~mL}^{-1}$ using a nematode counting slide under an optical microscope. The inoculum was pipetted into four 3-cm deep, equidistant holes made in the soil surrounding each plant. Treated uninoculated plants were used as negative control.

\section{Determination of nematode population density}

At 60 days after inoculation, the plants were removed from the pots and separated into shoots and roots. The root system was then thoroughly washed under running water to remove excess soil. Then, tuberous roots were peeled off to remove bark layers of approximately $3 \mathrm{~mm}$ of thickness. These and the secondary roots were weighed and subjected to nematode extraction according to a standard procedure [1]. The number of nematodes $\mathrm{g}^{-1}$ root was also calculated.

\section{Determination of vegetative parameters}

Shoot height, expressed in centimetres, was measured with a millimetre ruler. Shoot and root fresh weights, expressed in grammes, were determined using a semianalytical balance. Shoot dry weight, expressed in grammes, was measured by placing shoot samples in paper bags and incubating the bags in a forced-air oven at $65^{\circ} \mathrm{C}$ until constant weight was reached $(72 \mathrm{~h})$.

\section{Determination of mineral composition}

Beetroots were grated, oven-dried at $70{ }^{\circ} \mathrm{C}$ to constant weight, ground using a Wiley knife mill, sieved through 20 -mesh $(0.841 \mathrm{~mm})$ sieves, and stored in glass jars until mineral extraction and determination.

Nitrogen $(\mathrm{N})$ content was determined by sulphuric acid digestion, followed by distillation in the presence of salts and catalysts and titration [19]. For determination of P, K, 
$\mathrm{Ca}, \mathrm{Fe}, \mathrm{S}, \mathrm{Cu}, \mathrm{Zn}$, magnesium $(\mathrm{Mg})$, and manganese $(\mathrm{Mn})$ contents, samples were subjected to nitric and perchloric acid extraction followed by analysis by flame atomic absorption spectroscopy using the appropriate hollowcathode lamp for each element [19]. Prior to B determination, the dried samples were ashed in a muffle furnace. Then, B contents were measured spectrophotometrically using azomethine $\mathrm{H}$. Mineral contents are expressed on a dry basis.

\section{Data analysis}

Data were subjected to analysis of variance (ANOVA) at the 5 and 10\% levels of significance, followed by Fisher's least significant difference (LSD) test for the factor elicitor treatment while for the nematode inoculation the means were differed by $\mathrm{T}$ test. All statistical analyses were performed using Sisvar software version 5.6.

\section{Results}

\section{Nematode population density}

Plants were inoculated with 1000 eggs $+\mathrm{J} 2$ of $M$. javanica and treated with potential defence elicitors. MOS, citrus biomass, and ASM treatments reduced $(p=0.1002)$ nematode population density in the roots of beetroot plants by $47.71,42.84$, and $39.47 \%$, respectively, compared with the control (Fig. 1). However, visually, there were galls on all plants, regardless of treatment.

\section{Vegetative development}

The factors elicitors and inoculation showed significant $(p=0.0268)$ interaction effects on shoot height (Table 1). Uninoculated beetroot plants treated with ASM had a lower shoot height $(21.10 \mathrm{~cm})$ than uninoculated plants treated with MOS or citrus biomass, which did not differ from each other or the control $(25.46-27.30 \mathrm{~cm})$. In inoculated plants, ASM treatment increased shoot height $(28.08 \mathrm{~cm})$ in relation to the control $(25.06 \mathrm{~cm})$ and MOS treatment $(25.14 \mathrm{~cm})$. In comparing uninoculated and inoculated plants, we observed that only ASM increased shoot height (by 33\%).

Interaction effects on root fresh weight were significant $(p=0.0061)$ (Table 1). Uninoculated plants treated with MOS or ASM had lower root fresh weight (2.23-2.76 g) than inoculated treated plants $(4.08-4.26 \mathrm{~g})$. The highest root fresh weight among uninoculated plants was observed in those treated with citrus biomass (3.97 g). In plants inoculated with $M$. javanica, all treatments increased root development in 66 to $80 \%$ in relation to the inoculated untreated control.

Elicitors, but not nematode inoculation, influenced shoot fresh weight (Fig. 2), observed that MOS (16.19 g) and ASM $(16.54 \mathrm{~g})$ increased $(p=0.0241)$ shoot fresh weight compared with the control (13.52 g).

\section{Mineral composition}

Products and inoculation had significant interaction effects on $\mathrm{Cu}$ content only (Table 2). However, there was a significant effect for $\mathrm{N}, \mathrm{Ca}, \mathrm{Mg}, \mathrm{Fe}$, and $\mathrm{Mn}$ contents when the factors were separately analysed. In other hand, $\mathrm{K}, \mathrm{S}$, and $\mathrm{B}$ contents were not affected.

$\mathrm{Cu}$ contents were 3.4 and 2.5 times higher in inoculated plants treated with MOS and ASM, respectively, than in control plants (Table 2). Interestingly, MOS and ASM treatments combined with $M$. javanica inoculation increased $(p=0.0268) \mathrm{Cu}$ contents 4 - to 5 -fold compared with uninoculated plants.

Treatment with potential elicitors altered the contents of $\mathrm{N}, \mathrm{Ca}, \mathrm{Mg}, \mathrm{Fe}$, and $\mathrm{Mn}$ in beetroots (Fig. 3). N content decreased $(p=0.0234)$ by about $20 \%$ with citrus biomass treatment compared with the control (Fig. 3a), but was not influenced by nematode inoculation. Potential elicitors reduced $(p=0.0396)$ Ca concentration $(15-22 \%)$ in beetroot plants compared with the control (Fig. 3b). Mg content did not increase with application of the products $(p=0.0866)$ (Fig. 3c), with treated plants showing levels equal to (MOS and citrus biomass) or lower (ASM) than that of the control. A neutral or negative effect of potential elicitors on nutrient accumulation was also observed for $\mathrm{Fe}$ and $\mathrm{Mn}$, with reductions of $40 \%$ in relation to the control in plants treated with MOS (Fig. 3d) and citrus biomass (Fig. 3e).

Phosphorus levels were negatively influenced $(p=0.0002)$ by nematode inoculation (Fig. 4a), with an average of $3.70 \mathrm{~g} \mathrm{~kg}^{-1}$ and $3.04 \mathrm{~g} \mathrm{~kg}^{-1}$ for uninoculated and inoculated plants. Mg (Fig. 4b; $p=0.0002$ ), Fe (Fig. 4c; $p=0.0018$ ), Mn (Fig. $4 \mathrm{~d} ; p=0.0002$ ), and $\mathrm{Zn}$ (Fig. 4e; $p=0.0078$ ) levels, on the other hand, were higher in plants inoculated with $M$. javanica than in uninoculated plants. Thus, the observed values for these nutrients were from $2.17 \mathrm{~g} \mathrm{~kg}^{-1}$ to $3.45 \mathrm{~g} \mathrm{~kg}^{-1}$ for $\mathrm{Mg} ; 198.12 \mathrm{~g} \mathrm{~kg}^{-1}$ to $336.06 \mathrm{~g} \mathrm{~kg}^{-1}$ for Fe; $88.01 \mathrm{mg} \mathrm{kg}^{-1}$ to $163.93 \mathrm{mg} \mathrm{kg}^{-1}$ for $\mathrm{Mn}$; and $29.74 \mathrm{t} \mathrm{mg} \mathrm{kg}^{-1}$ o $37.24 \mathrm{mg} \mathrm{kg}^{-1}$ for $\mathrm{Zn}$, considering uninoculated and inoculated plants, respectively.

\section{Discussion}

MOS, citrus biomass, and ASM were effective in reducing $M$. javanica population densities in the roots of beetroot plants (Table 1), but did not prevent gall formation, according to visual analysis. Such effects were exerted indirectly, because the treatments were applied by foliar spraying and had no contact with the nematode, indicating that compounds successfully induced plant resistance to nematodes.

Each product has a distinct mode of action. MOS, for instance, is composed of phosphorylated mannanoligosaccharides from $S$. cerevisiae cell walls. The product showed potential in the control of root-knot nematodes 


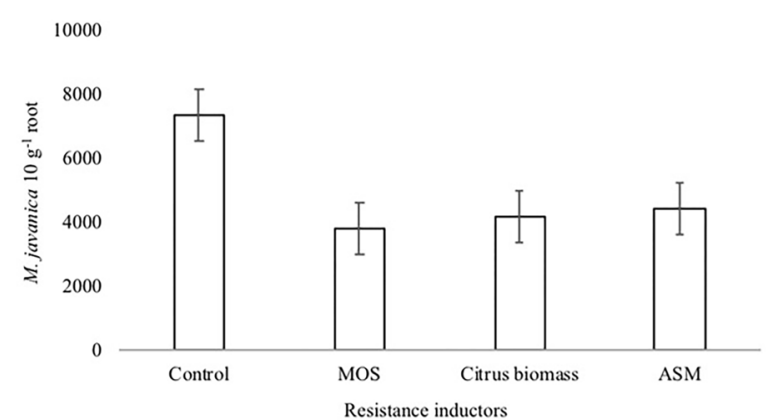

Fig. 1 Meloidogyne javanica population density (nematodes $10 \mathrm{~g}^{-1}$ root) in beetroots treated with potential defence elicitors. Different letters indicate significant differences between treatments (Fisher's least significant difference test, $p \leq 0.10$ )

Table 1 Vegetative parameters of beetroot plants treated with potential defence elicitors and inoculated with Meloidogyne javanica

\begin{tabular}{|c|c|c|c|c|}
\hline \multirow[t]{2}{*}{ Treatments } & \multicolumn{2}{|c|}{ Shoot height $(\mathrm{cm})$} & \multicolumn{2}{|c|}{ Root mass (g) } \\
\hline & $-\mathbf{M j}$ & $+\mathbf{M j}$ & $-\mathbf{M j}$ & $+M j$ \\
\hline Control & $27.30 \mathrm{aA}$ & $25.06 \mathrm{bA}$ & $2.69 \mathrm{bA}$ & $2.37 \mathrm{bA}$ \\
\hline MOS & $25.46 \mathrm{aA}$ & $25.14 \mathrm{bA}$ & $2.23 \mathrm{bB}$ & $4.08 \mathrm{aA}$ \\
\hline Citrus biomass & $25.60 \mathrm{aA}$ & $25.80 \mathrm{abA}$ & $3.97 \mathrm{aA}$ & $4.26 \mathrm{aA}$ \\
\hline ASM & $21.10 \mathrm{bB}$ & $28.08 \mathrm{aA}$ & $2.76 \mathrm{bB}$ & $3.94 \mathrm{aA}$ \\
\hline CV (\%) & 8.45 & & 20.68 & \\
\hline
\end{tabular}

Means within columns followed by different lowercase letters and means within rows followed by different uppercase letters do not differ significantly by Fisher's least significant difference test $(p \leq 0.05)$. CV, coefficient of variation; - , absence of nematodes; + , presence of nematodes

in lettuce, rice, and soybean, attributed to its capacity to induce plant resistance against the pathogen [21,31,33]. This hypothesis was confirmed in a study showing that MOS enhanced phenylalanine ammonia-lyase, catalase, peroxidase, and glucanase activities in rice infected with Meloidogyne graminicola [31]. The commercial product also contains $\mathrm{S}, \mathrm{Cu}$, and $\mathrm{Zn}$, which are cofactors of various plant enzymes and influence the formation and composition of plant cell walls. The nutrients contribute to plant resistance by producing toxic substances or forming a physical barrier against nematode penetration, affecting pathogen activity [21].

Citrus extracts are known to promote the synthesis of toxic substances, such as phytoalexins [27], which explains the efficiency of citrus biomass (Ecolife) against the plant-parasitic nematode. The reducing effect of this commercial product on root lesion numbers was observed in soybean and maize [18, 25]. However, research on the efficiency of this product is still incipient. ASM, in turn, is one of the most widely used inductors

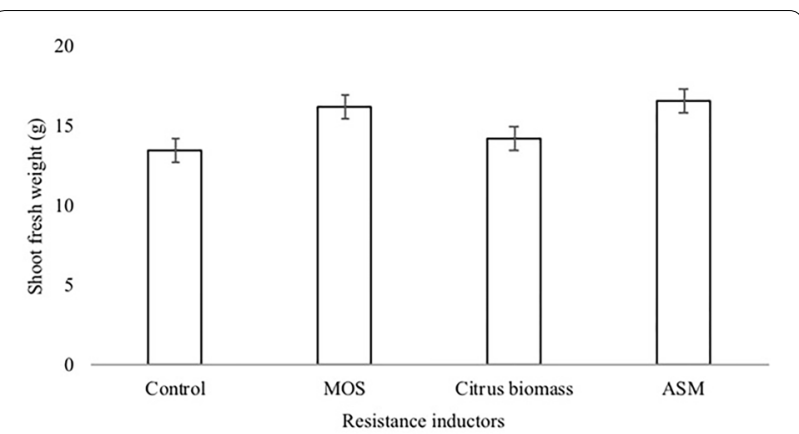

Fig. 2 Effect of potential defence elicitors on the shoot fresh weight of beetroot plants. Different letters indicate significant differences between treatments (Fisher's least significant difference test, $p \leq 0.05$ )

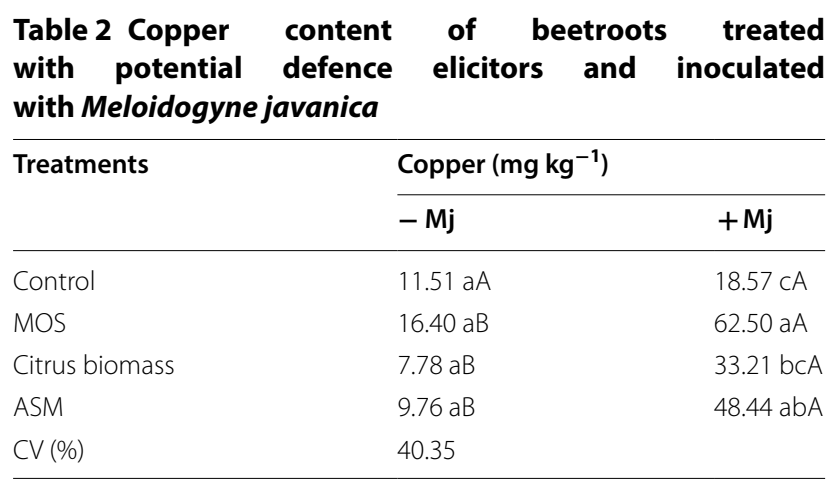

Means within columns followed by different lowercase letters and means within rows followed by different uppercase letters do not differ significantly by Fisher's least significant difference test $(p \leq 0.05)$. CV, coefficient of variation; - , absence of nematodes; + , presence of nematodes

for pathogen control, and its effectiveness in inducing defence responses against nematodes has been widely reported [24]. Because ASM is a salicylic acid analogue, it can activate systemic acquired resistance responses, leading to a pronounced effect on root-knot and lesion nematodes [24, 26].

Application of MOS, citrus biomass, and ASM contributed to the vegetative development of nematodeinoculated beetroot plants. These results are evidence of the sensitivity of beetroot to root-knot nematodes [7] and underscore the importance of the protective effect by resistance inducers [35]. Plant growth may also have been stimulated by the presence of nutrients in MOS and citrus biomass. Citrus biomass has a high content of organic compounds, which can positively contribute to the use of nutrients by plants [27], increasing vigour and disease resistance. As a result, plants may exhibit enhanced vegetative performance, even when inoculated (up to a certain level) with pathogens [16]. Other research has already shown the potential of resistance inducers, such as methyl salicylate, to increase the seedling emergence 


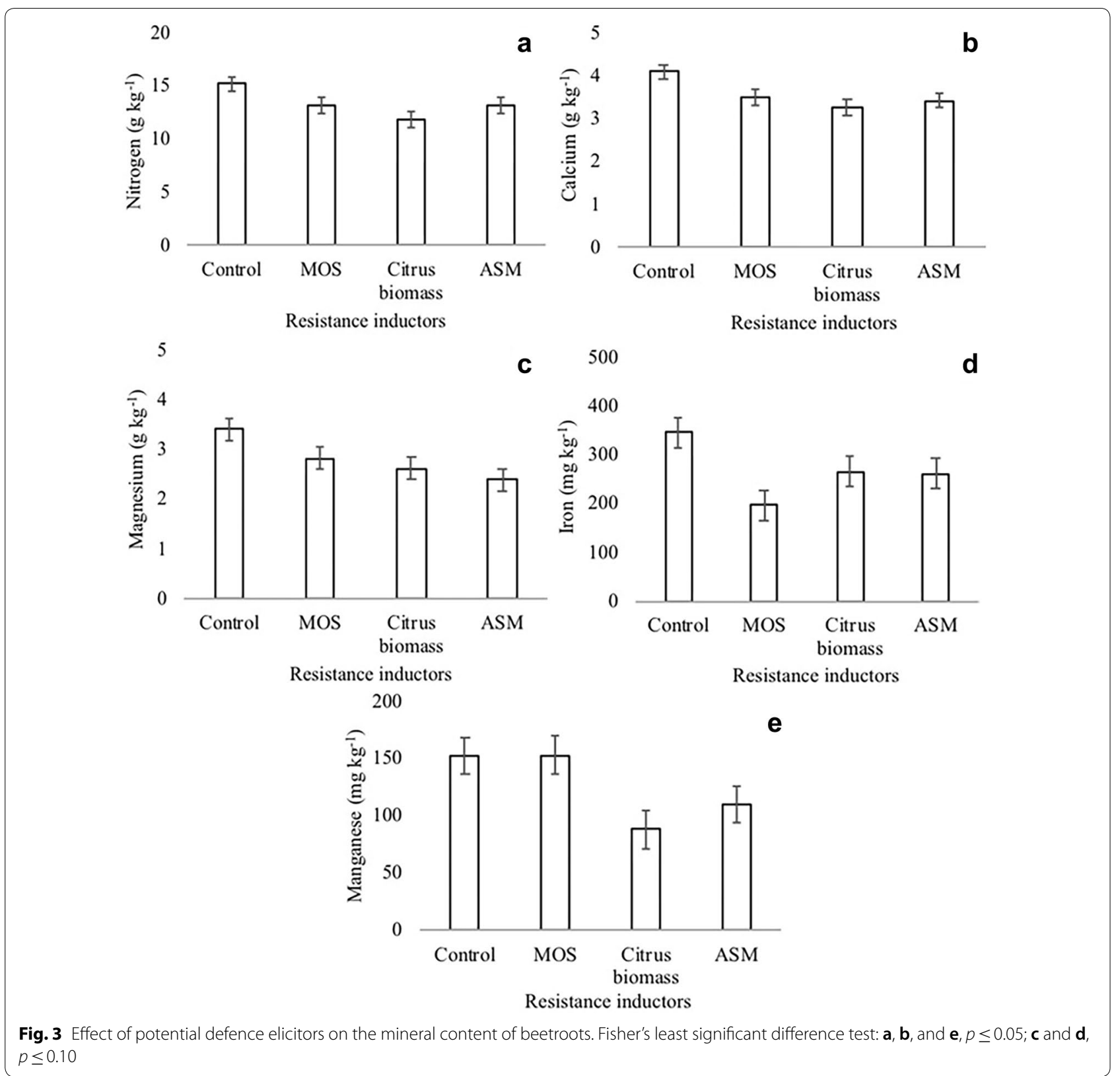

and plant growth in different cultivars of rice, however, with a dose-dependent effect in relation to cultivars [17]. In addition, the use of environmentally friendly bio-fertilisers, such as algae extracts, improve plant development, with an increase in germination and seedling vigour $[3,4]$ and in the levels of phenols and ascorbic acid [3].

The fact that uninoculated potential elicitors-treated beetroots had similar or poorer vegetative development than untreated plants can be explained by the energy expended to activate defence mechanisms. The metabolic pathways involved in plant defence responses can be activated by elicitors or pathogens, with relatively high energy costs [9]. The results show that some elicitors should be applied in the case of nematode infection, but their use should be avoided in noninfested fields.

Plant-pathogen-nutrient interaction mechanisms are complex and little understood. The nutrients assessed in the current study are essential for plant growth and development and participate in various physiological processes, such as regulatory protein synthesis, photosynthetic electron transport, mitochondrial respiration, oxidative stress responses, cell wall metabolism, and hormonal signalling $[10,19,29]$. Nutrients can also act as cofactors for enzymes associated with flavonoid and 


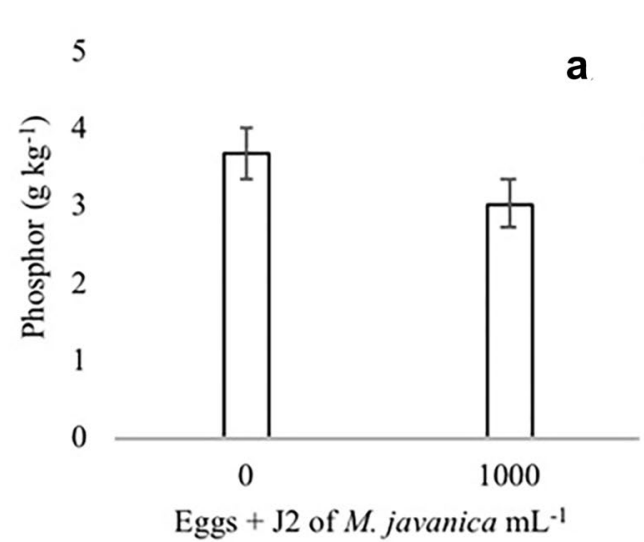

500

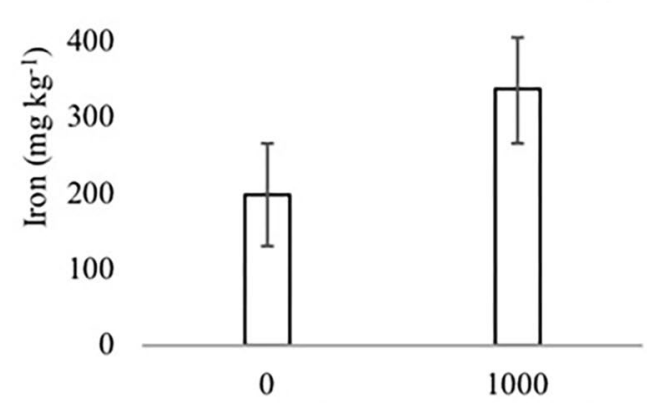

Eggs $+\mathrm{J} 2$ of $M$. javanica $\mathrm{mL}^{-1}$
5

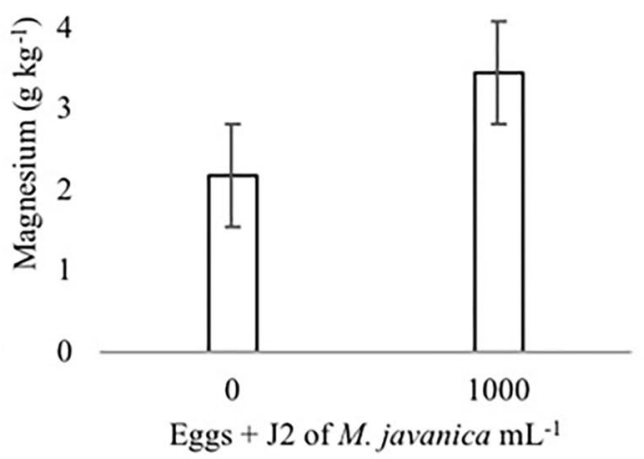

250

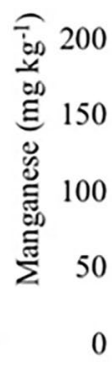

0

50

e

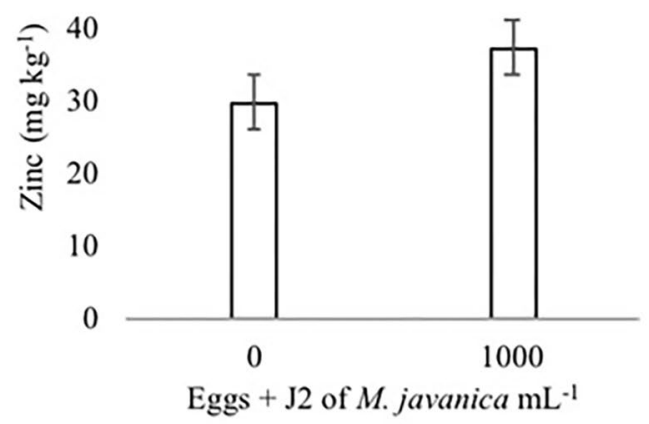

Fig. 4 Effect of Meloidogyne javanica infection on the mineral content of beetroots. Fisher's least significant difference test: a-e, $p \leq 0.05$

lignin synthesis [36], indispensable for physical protection against nematode penetration [10, 22, 29].

Overall, $\mathrm{N}, \mathrm{Ca}, \mathrm{Mg}, \mathrm{Fe}$, and $\mathrm{Mn}$ levels were lower in potential elicitors-treated plants, indicating that activation of defence mechanisms increases energy consumption and redirects nutrients to structural components [9]. Most of these nutrients are related to the synthesis of lignin and phytoalexins $[13,30]$ and are, therefore, highly consumed by a variety of metabolic pathways.
In contrast, $\mathrm{Mg}, \mathrm{Fe}, \mathrm{Mn}$, and $\mathrm{Zn}$ contents were higher in plants inoculated with the nematode. A previous study showed that $\mathrm{N}$ and $\mathrm{Ca}$ accumulate in the roots and are present at lower concentrations in the shoots of soybean infected with root-knot nematodes [2]. The authors attributed these results to the increase in root weight, as also observed in the present study. Root-knot nematodes induce complex feeding sites, to which nutrients absorbed by the plant are mobilised for nematode 
nutrition; each feeding site acts as a nutrient drain [2, 7]. The high metabolic activity required for protein synthesis explains the high micronutrient content of inoculated plants; most of the evaluated nutrients are cofactors of enzymes that are essential for plant defence [8, 29]. Proteins may also have been transported from conductive vessels to nematode feeding sites, as observed in syncytia $[7,14]$. The $\mathrm{Cu}$ content of inoculated plants was positively influenced by MOS and ASM, probably because of the increased root weight. Transpiration may have been increased under nematode infection, as suggested by a study showing that $\mathrm{Ca}$ concentrations in potato are higher under cyst nematode infection because of increased respiration rates [11].

Contrary to that observed for the other nutrients, $\mathrm{P}$ was found at lower concentrations in inoculated plants than in uninoculated plants. Studies have shown that $\mathrm{P}$ accumulates in roots or shoots depending on the level of infection [2]. It is possible that the high metabolic activity of infected plants, directed toward secondary root production and defence system activation, promoted the consumption of absorbed P. Further studies are needed to better understand the relationship between P levels and nematode infection.

It is noteworthy that the nutrient contents of nematode-infected beetroots were similar to or higher than those reported in the literature [34]. This result is important from a technical point of view. Nematode-affected beetroots are visually and texturally damaged by gall formation, which decreases their commercial value. Nevertheless, because of their high nutrient content, these vegetables can be used for extraction of minerals and pigments [28]. Beetroots are rich in betalains [6], and studies have shown that $M$. javanica infection does not affect the antioxidant power of beetroot [7].

\section{Conclusions}

Potential defence elicitors increased shoot fresh weight and reduced $M$. javanica population density in beetroot. Shoot height and root fresh weight were higher in nematode-inoculated plants. Uninoculated treated plants, however, had lower nutrient contents. Although potential elicitors reduced nematode population density, it did not prevent gall formation, a defect that decreases consumer acceptance and crop value. Nevertheless, nematodeaffected beetroots may be used in the food industry as sources of betalains and nutrients.

\section{Abbreviations}

K: Potassium; Na: Sodium; P: Phosphorus; Ca: Calcium; Fe: Iron; MOS: Mannanoligosaccharides; S: Sulphur; Cu: Copper; Zn: Zinc; B: Boron; ASM: AcibenzolarS-methyl; J2: Second-stage juveniles; N: Nitrogen; Mg: Magnesium; Mn: Manganese.

\section{Acknowledgements}

The authors thank the Brazilian Federal Agency for Support and Evaluation of Graduate Education (CAPES) for awarding a scholarship to PJGD and the Brazilian National Council for Scientific and Technological Development (CNPq) for funding the research and granting a research productivity fellowship to CRDA.

\section{Authors' contributions}

All authors contributed equally to the research and agree with the submission of the manuscript to the journal. All authors read and approved the final manuscript.

\section{Funding}

This work was supported by Brazilian National Council for Scientific and Technological Development (CNPq), Brazil [Project n 402136/2016-0].

\section{Availability of data and materials}

Additional data may be availed on request to the authors through the corresponding author. We take legal responsibility for information, used procedures, data and results.

\section{Ethics approval and consent to participate}

The research does not involve animals or humans or any other approach that requires ethical approval or consent to participate.

\section{Consent for publication}

Not applicable.

\section{Competing interests}

The authors declare no competing interests.

\section{Author details \\ ${ }^{1}$ Departamento de Agronomia, Programa de Pós-Graduação em Agronomia, Universidade Estadual de Maringá, Avenida Colombo, 5790, Maringá, PR CEP 87020-900, Brazil. ${ }^{2}$ Departamento de Tecnologia, Universidade Estadual de Maringá, Avenida Ângelo Moreira da Fonseca, 1800, Umuarama, PR CEP 87506-370, Brazil.}

Received: 17 July 2020 Accepted: 5 October 2020

Published online: 24 December 2020

\section{References}

1. Boneti JIS, Ferraz S. Modificação do método de Hussey \& Barker para extração de ovos de Meloidogyne exígua em raízes de cafeeiro. Supl Fitopatol Bras. 1981;6:553.

2. Carneiro RG, Mazzafera P, Ferraz LCCB, Muraoka T, Trevelin PCO. Uptake and translocation of nitrogen, phosphorus and calcium in soybean infected with Meloidogyne incognita and M. javanica. Fitopatol Bras. 2002;27:141-50.

3. Chanthini KMP, Senthil-Nathan S, Stanley-Raja V, Thanigaivel A, Karthi S, Sivanesh H, Sundar NS, Palanikani R, Soranam R. Chaetomorpha antennina (Bory) Kützing derived seaweed liquid fertilizers as prospective bio-stimulant for Lycopersicon esculentum (Mill). Biocatal Agric Biotechnol. 2019;20:101190.

4. Chanthini KMP, Stanley-Raja V, Thanigaivel A, Karthi S, Palanikani R, Sundar NS, Sivanesh H, Soranam R, Senthil-Nathan S. Sustainable agronomic strategies for enhancing the yield and nutritional quality of wild tomato, Solanum lycopersicum (L.) var cerasiforme Mill. Agronomy. 2019;9:331.

5. Chaves A, Pedrosa ER, Willadino L, Cardoso MSO. Activation of resistance to Meloidogyne incognita in sugarcane treated with pyraclostrobin. Nematoda. 2016;3:1-7.

6. Clifford T, Howatson G, West DJ, Stevenson EJ. The potential benefits of red beetroot supplementation in health and disease. Nutrients. 2015;7:2801-22.

7. Débia PJG, Bolanho BC, Puerari HH, Dias-Arieira CR. Meloidogyne javanica parasitism and its impacts on the vegetative parameters, physicochemical composition, and antioxidant potential of beet. Pesq Agropec Bras. 2019;54:e00695. 
8. Dias-Arieira CR, Santana-Gomes SM, Puerari HP, Fontana LF, Ribeiro LM, Mattei D. Induced resistance in the nematodes control. Afr J Agric Res. 2013:8:2312-8

9. Dietrich R, Ploss K, Heil M. Constitutive and induced resistance to pathogens in Arabidopsis thaliana depends on nitrogen supply. Plant Cell Environ. 2004;27:896-906

10. Dordas C. Role of nutrients in controlling plant diseases in sustainable agriculture-a review. Agron Sustain Dev. 2008;28:33-46.

11. Evans K. Water use, calcium uptake and tolerance of cyst-nematode attack in potatoes. Potato Res. 1982;25:71-88.

12. Gharibzahedi SMT, Jafari SM. The importance of minerals in human nutrition: bioavailability, food fortification, processing effects and nanoencapsulation. Trends Food Sci Technol. 2017;62:119-32.

13. Graham RD. Effect of nutrient stress on susceptibility of plants to disease with particular reference to the trace elements. Adv Bot Res. 1983;10:221-76.

14. Hoth S, Schneidereit A, Lauterbach C, Scholz-Starke J, Sauer N. Nematode infection triggers the de novo formation of unloading phloem that allows macromolecular trafficking of green fluorescent protein into syncytia. Plant Physiol. 2005;2005(138):383-92.

15. Hussain M, Kamran M, Singh K, Zouhar M, Rysánek P, Anwar SA. Response of selected okra cultivars to Meloidogyne incognita. Crop Prot. 2016;82:1-6.

16. Jiang CH, Xiea P, Li K, Xiea YS, Chenc LJ, Wangd JS, Xua Q, Guoa JH. Evaluation of root-knot nematode disease control and plant growth promotion potential of biofertilizer Ning shield on Trichosanthes kirilowii in the field. Braz J Microbiol. 2018:49:232-9.

17. Kalaivani K, Kalaiselvi MM, Senthil-Nathan S. Effect of methyl salicylate (MeSA), an elicitor on growth, physiology and pathology of resistant and susceptible rice varieties. Sci Rep. 2016;6:34498.

18. Kath J, Dias-Arieira CR, Ferreira JCA, Homiak JA, Silva CR, Cardoso CR. Control of Pratylenchus brachyurus in soybean with Trichoderma spp. J Phytopathol. 2017:165:01-9.

19. Malavolta E, Vitti GC, Oliveira S. Avaliação do estado nutricional das plantas: princípios e aplicações. Potafos;1997.

20. Melakeberhan H. Plant, nematode and nutrient relations: an overview. Jpn J Nematol. 1997;27:41-51.

21. Miamoto A, Silva MTR, Dias-Arieira CR, Puerari HH. Alternative products for Pratylenchus brachyurus and Meloidogyne javanica management in soya bean plants. J Phytopathol. 2017;165:635-40.

22. Ohri P, Pannu SK. Effect of phenolic compounds on nematodes-a review. J Appl Nat Sci. 2010:2:344-50.

23. Preczenhak AP, Tessmer MA, Berno ND, Vieira APA, Kluge RA. Initial stages of minimal processing of red beets result in significant loss of bioactive compounds. Food Sci Technol. 2018;96:439-45.
24. Puerari HH, Dias-Arieira CR, Dadazio TS, Mattei D, Silva TRB, Ribeiro RCF. Evaluation of acibenzolar-S-methyl for the control of Meloidogyne javanica and effects on the development of susceptible and resistant soybean. Trop Plant Pathol. 2013;38:44-8.

25. Puerari HH, Dias-Arieira CR, Tavares-Silva CA, Arieira JO, Biela F, Poletine JP. Ecolife ${ }^{\circledR}$ and manganese phosphite in the control of Meloidogyne javanica and in the development of soybean cultivars susceptible and resistant to the nematode. Nematropica. 2013;43:105-12.

26. Puerari $\mathrm{HH}$, Miamoto A, Jardinetti VA, Schwan-Estrada KRF, Dias-Arieira CR. Enzymatic activity induced by acibenzolar-S-methyl for control of Pratylenchus brachyurus in maize. J Plant Physiol Pathol. 2019;7:3.

27. Quinabra. Ecolife ${ }^{40}$ - Estimulando as plantas a produzir suas próprias defesas. Boletim Técnico, 2009.

28. Ravichandran K, Saw NMMT, Mohdaly AAA, Gabr AMM, Kastell A, Riedel H, Cai Z, Knorr D, Smetanska I. Impact of processing of red beet on betalain content and antioxidant activity. Food Res Int. 2013;50:670-5.

29. Santana-Gomes SM, Dias-Arieira CR, Roldi M, Dadazio TS, Marini PM Barizão DAO. Mineral nutrition in the control of nematodes. Afri J Agric Res. 2013;8:2413-20.

30. Sharma CP. Plant micronutrients. Lucknow: Science Publishers; 2006.

31. Soares MRC, Dias-Arieira CR. Induction of resistance to Meloidogyne graminicola in rice. Can J Plant Pathol. 2020. https://doi. org/10.1080/07060661.2020.1778789.

32. Tivelli S, Factor TL, Teramoto JRS, Fabri EG, Moraes ARA, Trani PE, May A. Beterraba: do plantio à comercialização. Boletim Técnico IAC, 210. Instituto Agronômico: Campinas; 2011.

33. Toninato $B O$, Souza DHG, Pontalti PR, Lopes APM, Dias-Arieira CR Meloidogyne javanica control in lettuce with fertilizers applied isolated or associated with biological product. Hortic Bras. 2019;2019(37):384-9.

34. United States Department of Agriculture (USDA). Agricultural Research Service, Nutrient Database for Standard Reference. Disponível em: https $: / /$ ndb.nal.usda.gov/ndb/foods/show/2900?fg=\&man=\&lfacet=\&forma $\mathrm{t}=\&$ count $=\& \mathrm{max}=25 \&$ offset $=\&$ sort $=\&$ qlookup $=$ beet. Accessed $21 \mathrm{Jan}$ 2020.

35. Walters DR, Ratsep J, Havis ND. Controlling crop diseases using induced resistance: challenges for the future. J Exp Bot. 2013;64:1263-80.

36. Yruela I. Copper in plants: acquisition, transport and interactions. Funct Plant Biol. 2009:36:409-30.

\section{Publisher's Note}

Springer Nature remains neutral with regard to jurisdictional claims in published maps and institutional affiliations.

\section{Submit your manuscript to a SpringerOpen ${ }^{\circ}$ journal and benefit from:}

- Convenient online submission

- Rigorous peer review

- Open access: articles freely available online

- High visibility within the field

Retaining the copyright to your article

Submit your next manuscript at springeropen.com 